\title{
Direito e Dominação no Horizonte da Existência*
}

\section{Aloysio Ferraz Pereira}

Professor Livre Docente de Filosofia do Direito da Faculdade de Direito da Universidade de São Paulo

Se é verdade, como escreveu RENÉ MARCIC, que a história da filosofia do direito é a dialética entre a teoria do direito natural e o positivismo jurídico, é também verdade, estendendo afirmação de HEIDEGGER, que os grandes juristas ou pensadores do direito pensaram a mesma coisa. E interessante observar como escritores, distantes no tempo e em suas ideologias, vêm a se aproximar quando abordam problemas fundamentais da teoria geral do direito. O espírito de escola, os partis pris se reduzem e desaparecem para deixar surgir, nos juízos mais profundos, algo de comum e de concorde. É que sob os conflitos do mundo empírico, como sob a dialética das idéias, os contrários deixam de o ser, e se encontram no concreto. Este é o plano do sentimento trágico e da compreensão hermenêutica, a cuja luz se pode manifestar o que é mais digno de ser vivido e de ser pensado. Sob reserva dessa unidade de fundo e dessa compreensão trágico-hermenêutica, onde todos, entes e existentes, em sendo nos encontramos no ser, havemos de observar as oposições em que os entes mudam e se deslocam; bem como o jogo calidoscópico das contrariedades e contradições em que espontaneamente se movimentam os termos e as categorias da lógica. Há os que, com justa razão, neste jogo se detêm; como há os que, também por gosto ou vocação, se debruçam sobre os fenômenos e processos sensíveis.

Assim, no campo dos estudos jurídicos, há lugar para quem prefere isolar nos fatos complexos a sua estrutura lógica e para aquele que acompanha e anota o seu curso necessário. Pois há o campo da lógica e o da sociologia do direito, entre outros. Mas o acesso à totalidade do jurídico não se dá aos que

* Comunicação ao $1^{\circ}$ Encontro Brasileiro de Filosofia do Direito, realizado em João Pessoa, setembro de 1980. 
se armaram cavaleiros da lógica e da sociologia, ou da axiologia, mas se abre ao homem na integridade de sua existência; noutras palavras: ao homem, enquanto ser-aí, em sua situação existencial.

Se, como entendemos, a tarefa do filósofo consiste em fundar, a da filosofia do direito reside em buscar e achar, mais que o fundamento teórico, o fundo de vida humana em que sempre e por toda parte mergulha e se move o fenômeno jurídico. E, para exercer este ofício, são dispensáveis, quando não atrapalham, diplomas e métodos, aparelhos críticos e técnicas eruditas. Pois estas coisas podem interpor-se à observação direta e desnaturar a experiência íntima dos fenômenos jurídicos. Podem, este o seu maior perigo, velar ao homem, tal como ele existe, o seu próprio ser, na sua miséria, na sua mortalidade, no seu sentido. Porque os recursos, tantas vezes úteis, da ciência, da técnica e da metafísica, têm a natureza das funções e preocupações do mundo disponível e inautêntico, onde o direito é mero instrumento e a visão da justiça foi obliterada.

Não há abismo intransponível nem ruptura entre direito e justiça, porque não há cisão irremediável entre o homem inautêntico e o autêntico. Da experiência originária, em que a filosofia do ser e da existência vê cada um de nós diante da transcendência e da liberdade para a morte, parte uma ponte natural, insensível passagem, que conduz à sua situação social e política e ao posicionamento no mundo da preocupação: à relação que o homem existente ocupa no sistema de produção em que se acha. Não há separação entre a situação limite, onde o cuidado define minha essência, onde o meu ser comunica com o ser em geral, $e$ a minha situação no regime de produção em que trabalho ou exploro. O privilégio da experiência da angústia ou a simples constatação do meu limite mortal abre-me a perspectiva da ontologia fundamental, na qual descubro minha função econômica e minha posição de classe.

Assim, a situação ôntico-ontológica é uma determinação de ser do homem existente, dada no horizonte de sua estrutura originária, mercê da compreensão ou sentimento dessa situação. Da mesma forma, a situação sócio-política do existente, que determina ao mesmo tempo o seu ser, de modo igualmente essencial e existencial, deriva da relação de produção em que se encontra e se translucida também através da hermenêutica, ou seja, por meio da compreensão ou do sentimento de classe. Então, ao revolver-se, em que se opera o eterno retorno do processo circular da hermenêutica, sucedem os possíveis movi- 
mentos dialéticos em que se estilhaçam os entes subsistentes e os movimentos dieréticos (como diria Platão) em que, infinitamente, divergem e colidem os discursos sobre os entes intra-mundanos.

A compreensão de seu a priori ôntico-ontológico conduz o homem existente à liberdade de optar por uma existência mais ou menos autêntica, isto é, mais ou menos conforme à sua vocação e natureza. Eis pois o homem sobre o difícil mas inevitável gume dialético, entre realizar aquilo para que veio ou ceder à alienação do divertissement pascaliano. Eis também o existente nesse campo instável e revolto em que se afrontam as classes, tão naturais e tão gritantemente reais, tão concretas quanto os indivíduos, que as compõem, e tão consistentes que possuem a duração da história dos povos e da humanidade.

No mundo da inautenticidade, o direito é uma ordem prática de soluções, que se organiza à luz da prudência e procura a segurança e a imobilidade. Razão prática e razão teórica, cada uma em seu plano, concorrem para dar ao direito a imutabilidade e a perenidade a que aspira o desejo humano em seu delírio. Assim falava Zaratustra: Ich liebe dich, o Ewigkeit (Eu te amo, ó eternidade). E NIETZSCHE vivia no século XIX, que foi a era triunfal do sonho burguês já hoje sonhado e findo (ausgeträumt). Leis eternas e imutáveis para a economia política, leis naturais, entendidas como em processo necessário, determinístico. Era a ingênua economia política dos clássicos ingleses e franceses. Leis imutáveis e eternas para 0. direito, insuscetíveis de interpretação outra que a legal, no Código Napoleão, onde se condensaram as regras do comércio e da propriedade individualista e liberal.

Então como agora, ergue-se o tecnicismo positivo para nos dizer que o direito visa ao controle social. Onde se lê controle social eu me permito ler: dominação de classe. E o positivismo técnico, tecnicista e tecnocrático perpetra, em seguida, sua fundamental hipocrisia, nestes termos: o direito conhece e manipula os meios, opera os instrumentos normativos da ordem social e deriva tudo do estado. Ao que costuma perguntar o inocente primeiranista: "Vamos então ver o que é o estado. E vamos indagar a que e a quem serve o direito" No que depender de seus professores ficará porém o nosso calouro, em geral, com sua irreverente curiosidade insatisfeita. Não é lícito nem científico nem conveniente deixar o profano do direito para aventurar-se no sagrado do estado. Do mesmo modo, não se deve sair do ius cotidiano para, como PARMÊNIDEs no seu 
Poema, forçar as portas da Justiça, ou melhor, colocar o problema dos fins do direito.

Não há abalar a cidadela do estado, onde a propriedade privada se levanta no topo intocável da acrópole jurídica.

Mas se a justiça permanece a virtude estranha, em favor de outrem, ela se torna, aceleradamente, cada vez mais, a virtude revolucionária. 0 seu nome - como o sol daquele poeta não é mencionado nas leis, mas se elas têm algum sentido, a sua força está em todas, "Le soleil n' est point nommé, mais sa force est partout" Que a expulsem ou que a admitam (digamos assim) no discurso das leis, a verdade é que se a justiça está nele sempre presente, aí não cabe inteira e o transcende, acompanhando o homem, que tampouco se esgota no súdito e no sujeito de direito. Parece que a fisionomia do direito-norma é séria como a de um comerciante bem sucedido ou de um burocrata patriota, mas que a justiça participa da natureza da tragédia. $\mathrm{O}$ direito é utensílio do estado, enquanto o estado é a classe dominante organizada e armada. A justiça é primordialmente, na história, impulso da vingança, da represália, a reparação forçada do dano, o talião. Ela é, primeiro, ação corretiva da injustiça, ou seja, justiça comutativa. Noutros termos: no começo é o crime, a privação, a carência, a falta, a negatividade; numa palavra, no começo é o nada que descobrimos em nós ou que se abateu sobre nós pela mão de outrem.

A justiça distributiva é uma noção teórica posterior, que pressupõe a autoridade que distribui ou garante a distribuição natural já realizada. Os romanos, após ARISTóteles, definiram-na: vontade firme e permanente de dar o seu bem, a sua coisa, o seu haver a cada um. São ToMÁs seguiu o seu Filósofo e, bom romanista, os seus jurisprudentes. E assim diziam todos a una voce: a cada um o seu haver segundo o seu mérito heróico. $\mathrm{E}$ quando as massas oprimidas de trabalhadores, concentradas nas cidades industriais da Europa, conheceram o efeito da dominação burguesa, forrada de racionalismo individualista e de neutralidade axiológica, ciosa das verdades de sua ciência, veio KARL MARX dizer-nos, como um eco, no seu Programa de Gotha, repetindo um socialista francês: "de cada um segundo a sua capacidade a cada um segundo a sua necessidade"

Aí está com mais um caminho, o de MARX, veio naturalmente prolongar o de ARISTóteles, o romano e o do Doutor Angélico. Nesta direção histórica, que poderíamos dizer da existência, essas filosofias encontraram vasto terreno comum onde amplamente se compatibilizam. 
Em ARISTóteles, entre os romanos, bem como em São Tomás e Marx, ou ainda em HEIDEGGER e SARTRE, por exemplo, no terreno da natureza da justiça e do direito, a existência precede a essência e a práxis sobreleva à teoria, a compreensão ôntica e existentiva se antecipa ao discurso degradado e à ontologia existencial, o ter é superior ao ser.

ARNOLD TOYNBEE assinalou, num ensaio, que a teoria de MARX sobre o modo capitalista de produção, vale dizer, sobre o sentido mesmo da civilização greco-latina atual, estava destinada a ser assimilada pela Rússia bizantina e oriental, e ser voltada contra o Ocidente, porque ela constitui uma inexorável crítica da Europa. Em nossos dias, HEIDEGGER, após o esforço enfático de NiETzSCHE de salvar os aburguesados valores da cultura de dominação, veio lançar sobre toda a civilização européia, sucessiva aos pré-socráticos, o anátema inapelável (e sobre que profundos fundamentos!) de niilismo. Para ele, como para HEGEL, a metafísica é a alma da história européia. Ora, a técnica tornou-se a essência da metafísica, como vontade. E, como tal, a metafísica se esvaziou, se nulificou. Quer dizer, em conclusão, que a civilização ocidental acabou em niilismo e que a Europa, em sua imagem atual, em seu espírito de dominação e de orgulho, como suas poderosas franjas dos outros continentes, não são mais do que o nada. A Europa, enquanto sistema neo-capitalista de valores, é pois o nada, de onde só nada sai: o nada do dominado sob o nada do dominador.

De onde esperar, portanto, e agora, o dom do ser, da plenitude e do sentido? A "salvação pelo selvagem" parece uma proposta possível. Um escabelo africano de $58 \mathrm{cms}$. de altura, com tampo sustentado por uma figura negra à maneira de cariátide, executado em madeira, no século xvI, por um mestre Luba, do Zaire, foi vendido em leilão, em Londres, há pouco mais de um ano, por US $\$ 492,000.00$. Eis como a Europa capitalista reconheceu, segundo o princípio do seu valor supremo, que é o valor de troca, o valor de uso do objeto de arte africano e o valor incomensurável do trabalho de seu humilde artista.

Voltando-nos para a realidade do nosso povo, do nosso país, de sua história, descobrimos o fundo original do nosso direito e o sentido de nossas instituições. Aí percebemos o quanto de opressivo e escravizante contém essa cultura européia, a que adere a classe dominante brasileira, em seu histórico papel de aliança com classes e governos estrangeiros metropo- 
litanos, na tarefa tradicional de subjugar nosso povo, para explorá-lo em benefício próprio.

Assim, a cultura européia, roída pelo nada, é mortal para os povos da sua soi-disant periferia. Só nos resta situar-nos como centro e sacudir de vez, e radicalmente, o jugo da dominação, rejeitando toda relação de dependência econômica, de que deriva, como de sua fonte e causa, a dependência cultural, tão certa como a essência decorre de e generaliza a existência. Tal é o programa que o direito brasileiro pode observar. Se não o fizer há de sempre estalar como utensílio imprestável ao empuxe da justiça, que é o gesto mesmo da revolta, da renovação e da vida. Nenhuma razão burguesa pode conter a revolução que se agita no ventre das massas, buscando a sua libertação na igualdade econômica. Quanto a nós, filósofos e juristas, penso que cabe o papel de, na mesma perspectiva de justiça, descobrir no movimento operário essa compreensão de classe que permite o desvelamento da verdade jurídica. 0 direito não pode se imobilizar na dogmática. Se, como diz HEIDEGGER, o homem é o pastor do ser, assim também o filósofo do direito será o pastor do ser-jurídico no grupo social, à escuta das necessidades do seu povo, para que todos os que trabalham possam decidir, sem mentira e sem medo, da própria situação e da sorte comum. É como se há de tender a uma economia de abundância, onde sejam satisfeitas solidariamente as necessidades materiais, para que cada um, no mundo e com os outros, tenha acesso ao Ser em seu próprio ser. 